\title{
Geochemical investigations regarding the variability of metal pollution in the Amvrakikos Bay, Greece
}

\author{
Diamantopoulou A. ${ }^{1}$, Kalavrouziotis I.K. ${ }^{1}$ and Varnavas S.P. ${ }^{2}$ \\ ${ }^{1}$ Hellenic Open University, School of Science and Technology, Tsamadou 13-15 \& Saint Andrea, 26222 Patras, Greece \\ 2Department of Geology, University of Patras, 26504 Patras, Greece \\ Received: 28/04/1998, Accepted: 31/07/2018, Available online: 26/09/2018 \\ https://doi.org/10.30955/gnj.002733
}

\begin{abstract}
The Amvrakikos Bay is one of the most important ecosystems in the Mediterranean with great environmental, ecological and biological value. However, over the years, water quality has suffered severe degradation and is now one of the most polluted environmental areas in Greece. In the present study, using the analytical data of concentrations of precipitated metal deposits at the bottom of Amvrakikos Gulf, at its three largest lagoons: Logaros, Tsoukalio and Rodia, and by applying the indicators $\mathrm{PLI}$, Igeo and $\mathrm{EF}$, an assessment of the level of pollution of the area was made. The use of these indicators may show the degree of pollution of the area with heavy metals, and reveal the source of pollution i.e. whether the heavy metals are of anthropogenic or of natural processes, assessing simultaneously the degree of anthropogenic effect. Based on the PLI indicator, the marine zone in Menidi and Paliovarka as well as the Rodia and Tsoukalio lagoons are considered to be polluted. According to the Igeo Index, the sampling areas are unchanged to slightly burden by heavy metals. The largest charge is caused by $\mathrm{Ni}$, followed by $\mathrm{Mn}$ and $\mathrm{Pb}$. Based on $\mathrm{EF}$, the concentrations of $\mathrm{Cr}, \mathrm{Mn}, \mathrm{Co}, \mathrm{Pb}$ and $\mathrm{Ni}$ are significantly influenced by the various anthropogenic activities.
\end{abstract}

Keywords: Amvrakikos, bay, metal pollution indices, marine sediment metal pollution, management of marine environment.

\section{Introduction}

The Amvrakikos Bay is located on the northwest coast of Greece. The area occupies about $400 \mathrm{~km}^{2}$ and is one of the largest semi-bays with particular morphology. It is characterized by a limited water renewal, as communication with the open sea is achieved only in the area of Preveza, through a narrow channel approximately $600 \mathrm{~m}$ wide. The bottom of the sea is covered with sludge and sand. The waters are blurred and show a strong eutrophication phenomenon (Bearzi et al., 2008). It presents high concentrations of nutrients, making it a highly productive habitat. The complex system of Amvrakikos lagoon includes at least 15 lagoons, with a total area of more than $70 \mathrm{~km}^{2}$. Their main characteristic is their small size, shallowness and their influence from a similar tidal effect on their opening (Christia and Papastergiadou, 2006).

Due to the limited water renewal, only coming from the surface waters of the Ionian Sea, the issue of Amvrakikos waters quality arises, especially in the deepest layers of the bay. Combined with the run-off to the northern part of the rivers, carrying sediments with organic material and increased concentrations of metals and nutrients, the existing situation is even worse. The major sources of pollution from human activities that burden the Amvrakikos Bay are, industrial waste water, sewage, surface run-off (mainly from agriculture and livestock farming).

Environmental geochemical studies can help in assessing the quality of the environment as well as the determination of the sources of pollutants, their behavior and other characteristics. This knowledge is necessary in any application of remediation methodologies and waste management for the prevention of pollutants in getting into the food chain and in determining safe criteria regarding the quality of soils and drinking water (Varnavas et al., 2012). Based on geochemical studies of marine sediments and waters, environmental conditions have been assessed in many Greek seas (Voutsinou et al., 1997) and Greek bays such as the Saronic Gulf (Sklivagou et al., 2008; Sklivagou et al., 2001), Thermaikos Gulf (Voutsinou and Varnavas, 1995), Patraikos Bay (Varnavas, 1991), Euboicos Bay (Voutsinou and Varnavas, 1985), but also in other small or large bays (Achilleopoulos and Varnavas, 1996; Varnavas et al., 2012; Varnavas, 1989; Varnavas et al., 1992; Voutsinou and Varnavas, 1992; Varnavas et al., 1987a; Panagos et al., 1989; Varnavas et al., 1987b; Varnavas et al., 1984) and lagoons (Varnavas, 2005), giving interesting results.

The aim of this paper is to assess the environmental status of the Amvrakikos Gulf water system, using the metal concentration data in sediment samples at the Amvrakikos Gulf, more specifically at its three largest lagoons: Logaros, Tsoukalio and Rodia, and by applying the indicators PLI, Igeo and EF, an assessment of the level of pollution of the 
area was made. The use of these indicators may show the degree of pollution of the area with heavy metals and reveal the source of pollution i.e. whether the heavy metals are of anthropogenic or of natural processes, assessing simultaneously the degree of anthropogenic effect.

\section{Materials and methods}

According to the study by Ferentinos et al. (2010), the bottom of the bay is covered by a uniform black layer of mud, 3-10 cm thick (Figures 1 and 2). The intense black color is the proof of the anoxic conditions prevailing at the bottom. As can be seen from the bottom profile, its clay content is estimated between 28 and 33\% while sludge ranges from 65 to $68 \%$. Sand fractions are less than $3 \%$ of the sediment. Underneath the black layer, another layer, greenish green and over $50 \mathrm{~cm}$ thick, is present. It contains $38-41 \%$ clay and $50-60 \%$ sludge. The black layer contains $5-8.6 \%$ total carbon (TOC), while the second layer contain only 5\% TOC, (Ferentinos et al., 2010).

In coastal water systems, the presence of metals, commonly referred to as heavy metals, is frequent. Some of these, such as aluminum and iron, have a natural presence and are found at high relative concentrations. Some others, such as mercury, cadmium, selenium etc., are rarely present and their concentrations are usually low. Human activities can produce industrial and municipal waste, agricultural residues etc., increasing the concentrations of heavy metals. As a consequence, they accumulate in fine sediments and living organisms, creating toxicity, causing dysfunction in organ functions and changes in population distribution and abundance.

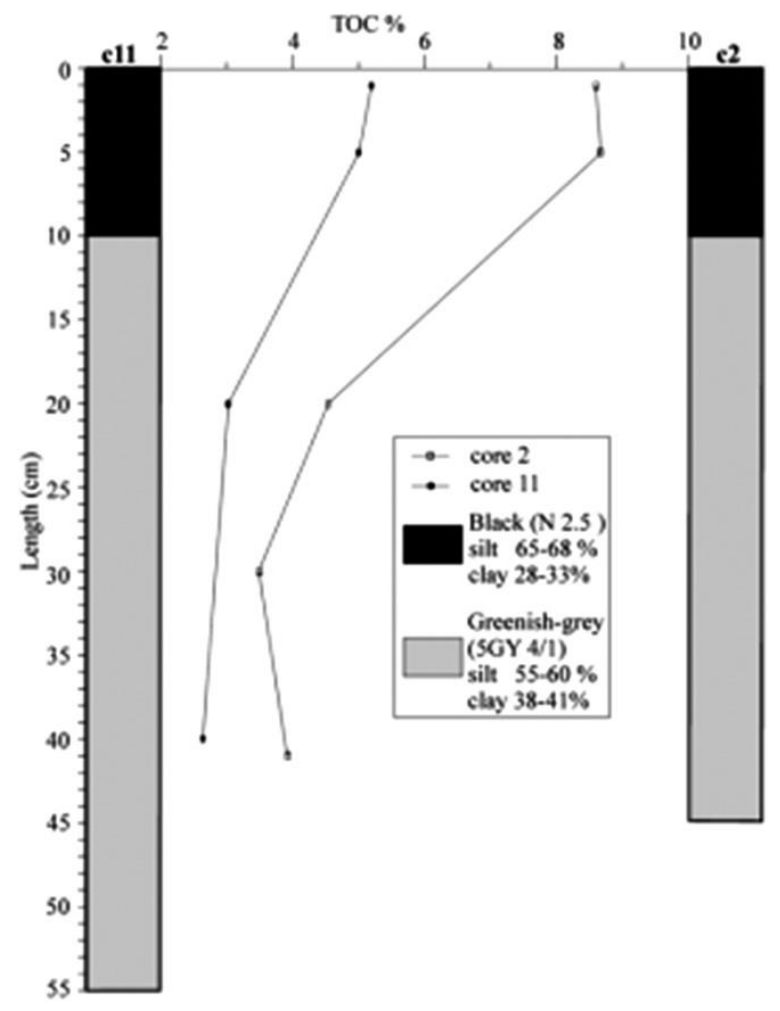

Figure 1. Bottom description and TOC profile, at two different locations in Amvrakikos (Ferentinos et al., 2010)
In Table 1, the data from the determination of heavy metals in sediments of the Amvrakikos Marine Region $(A 2, A 10, A 12, A 14)$ and lagoons $(L 1, L 2, L 3)$ in December 2009 (Amvrakikos Management Consortium, 2009), are presented. The data were used in the research project "Development of Management Tools and Drafting of a Master Plan of the hydrological basins of the rivers Louros and Arachthos and Amvrakikos Bay". Sampling sites were chosen so as to reflect in extended range fitness Amvrakikos Gulf.

- A2. Pogonitsa (38 $\left.57^{\circ} 37.05^{\prime \prime N}, 20^{\circ} 48^{\prime} 34.50^{\prime \prime} \mathrm{E}\right)$. A2 station, $8.5 \mathrm{~m}$ deep, is close to two large aquaculture units. It is also representative of the northern part of the Gulf.

- $\quad$ A10. Menidi (39 ${ }^{\circ} 1^{\prime} 39.70$ "N, $\left.21^{\circ} 77^{\prime} 7.88^{\prime \prime} E\right)$. The station A10, $14.6 \mathrm{~m}$ deep, is located outside the Menidi City Center. It is also close to large fish farms.

- A12. Paliovarka (3854'6.39 "N, $\left.21^{\circ} 3^{\prime} 36.45^{\prime \prime} \mathrm{E}\right)$. The A12 station, $20 \mathrm{~m}$ deep, is representative of the conditions prevailing in the southern part of the Amvrakikos Gulf between the two urban centers of Vonitsa and Amfilochia.

- A14. Vonitsa (38 $58^{\circ} 10.47$ "N, $\left.20^{\circ} 53^{\prime} 43.21^{\prime \prime} \mathrm{E}\right)$ The $\mathrm{A} 14$ station, $14 \mathrm{~m}$ deep, is located in the port of Vonitsa.

- L1. Rodia (39 ${ }^{\circ} 5^{\prime} 19.57$ "N, $\left.20^{\circ} 48^{\prime} 41.20^{\prime \prime} \mathrm{E}\right), \mathrm{L} 2$. Tsoukalio (39 ${ }^{\circ} 3^{\prime} 38.07$ "N, $\left.20^{\circ} 49^{\prime} 42.60^{\prime \prime} \mathrm{E}\right)$ and L3. Logarou (39 $\left.{ }^{\circ} 2^{\prime} 33.55^{\prime N} \mathrm{~N}, 20^{\circ} 54^{\prime} 33.11^{\prime \prime} \mathrm{E}\right) \mathrm{L} 1$, depths of $3.03 \mathrm{~m}, \mathrm{~L} 2$, depth $1.6 \mathrm{~m}$ and L3 $1.8 \mathrm{~m}$ deep, are representative of biotic and abiotic conditions prevailing in the three largest and most important lagoons of the North Amvrakikos Gulf.

The high content of heavy metals, in the lagoon sediment, is due to the geological composition of their soils (Karageorgis, 2007). In the lagoons of Rodia and Tsoukalio, we can observe, higher values of lead concentration than in the rest of the bay, associated with the anoxic conditions of the bottom of the two lagoons (Calvert et al., 2001).

The data of Table 1 are expressed in dry $\mu \mathrm{g} / \mathrm{g}$ weight of sediment. Concentrations of metals were measured by atomic absorption spectrometry.

\section{Heavy metal pollution indices}

Estimation of pollution levels in the bottom sediment of a coastal area is based on a series of indicators, such as:

\subsection{Pollution load index, PLI}

The Pollution Load Index (PLI) is the concentration of each heavy metal relative to the metal concentration value in an average non-polluted precipitate. The index is calculated as follow (Tomlinson et al., 1980):

a) Concentration Factor (CF) for each metal and at each sampling location:

$\mathrm{CF}=\mathrm{C}$ metal $/ \mathrm{C}$ background value 
C metal: metal concentration in polluted sediments

C background value: background value of that metal.

The background concentrations of the respective metals Enrichment Factor are shown in Table 2.

b) Calculation for each sampling point of the total charge of all heavy metals:

$$
\begin{array}{ll}
\text { PLI } \quad \text { sampling } & \text { position } \\
(\mathrm{CF} 1 \times \mathrm{CF} 2 \times \mathrm{CF} 3 \times \ldots \times \mathrm{CFk})^{1 / \mathrm{k}} &
\end{array}
$$

CFk: the pollution factor of the k-bone metal at the specific sampling site

k: number of metals

c) Sampling positions displaying a similar PLIlocation are grouped into bands and the pollutant load index (PLI) for each zone is calculated as follow:

PLI zone $=(\mathrm{PLI} 1 \times \mathrm{PLI} 2 \times \ldots \times \mathrm{PLIm})^{1 / \mathrm{m}}$

PLIm: the pollutant of the $m$-th sampling position $\mathrm{m}$ : the number of sampling sites constituting that zone

d) Calculation of the general pollution load index for the studied sea bay, or lake according to the individual indicator of the zones based on the ratio:

$\mathrm{PLI}$ environment $=(\mathrm{PLI} \times \mathrm{PLI} 2 \times \ldots \times \mathrm{PLIn})^{1 / n}$
PLIn: the pollutant of the $n$-th zone

$\mathrm{n}$ : the number of zones constituting the particular environment.

\subsection{Geoaccummulation index, Igeo}

The Geoaccumulation Index (Igeo) compares the current concentrations of heavy metals in a sample to the corresponding pre-industrial levels. The index is expressed as follow (Muller, 1969):

$$
\text { Igeo }=\log 2 \mathrm{Cn} /(1.5 \times \mathrm{Bn})
$$

$\mathrm{Cn}$ : measured concentration of element $\mathrm{n}$ in the sediments $\mathrm{Bn}$ : geochemical background for the element $\mathrm{n}$

1.5: is used to minimize lithological effects.

\subsection{Enrichment factor, $E F$}

The Enrichment Factor (EF) is expressed as follow (Huu, 2010):

$$
\begin{aligned}
& \mathrm{EF}=\text { (Tracer/Normalizer) sample/ } \\
& \text { (Tracer/Normalizer) background }
\end{aligned}
$$

Where (tracer/normalizer) Sample and (tracer/normalizer) background respectively are the concentrations of metals (in $\mu \mathrm{g} / \mathrm{g}$ of dry sample) in the sample and in the non-contaminated area.

Typically, as a normalizer we use a reference metal whose concentration is not due to anthropogenic effect. Such metals are iron and aluminum (Mediolla et al., 2008).

Table 1. Concentrations of heavy metals in sediments of the Amvrakikos sea area and lagoons (Amvrakikos Management Consortium, 2009)

\begin{tabular}{cccccccc}
\hline Metals & $\mathrm{Cu} \mu \mathrm{g} / \mathrm{g}$ & $\mathrm{Cr} \mu \mathrm{g} / \mathrm{g}$ & $\mathrm{Ni} \mu \mathrm{g} / \mathrm{g}$ & $\mathrm{Co} \mu \mathrm{g} / \mathrm{g}$ & $\mathrm{Mn} \boldsymbol{\mu g} / \mathrm{g}$ & $\mathrm{Pb} \mu \mathrm{g} / \mathrm{g}$ & $\mathrm{Zn} \mu \mathrm{g} / \mathrm{g}$ \\
\hline EF - A2 & 27.9 & 86.8 & 310 & 32.5 & 1487 & 31.2 & 28.1 \\
\hline EF - A10 & 36.1 & 71.3 & 203 & 27.1 & 1172 & 21.1 & 43.5 \\
\hline EF - A12 & 47.3 & 76.9 & 223 & 31.2 & 484 & 28.1 & 50.1 \\
\hline EF - A14 & 19.7 & 27.5 & 68.6 & 22.9 & 896 & 33.6 & 17.3 \\
\hline EF - L1 & 34.9 & 68.5 & 161 & 28.0 & 941 & 43.0 & 39.6 \\
\hline EF - L2 & 34.5 & 107.8 & 154 & 28.8 & 957 & 39.7 & 40.9 \\
\hline EF - L3 & 29.8 & 57.0 & 146 & 27.5 & 1058 & 30.0 & 29.1 \\
\hline
\end{tabular}

Table 2. Heavy metal background table (Turekian and Wedepohl, 1961)

\begin{tabular}{ccccccccc}
\hline Metals & $\mathrm{Cu} \mu \mathrm{g} / \mathrm{g}$ & $\mathrm{Cr} \mu \mathrm{g} / \mathrm{g}$ & $\mathrm{Ni} \mu \mathrm{g} / \mathrm{g}$ & $\mathrm{Pb} \mu \mathrm{g} / \mathrm{g}$ & $\mathrm{Zn} \mathrm{g} / \mathrm{g}$ & $\mathrm{Co} \mu \mathrm{g} / \mathrm{g}$ & $\mathrm{Mn} \mu \mathrm{g} / \mathrm{g}$ & $\mathrm{Fe} \mu \mathrm{g} / \mathrm{g}$ \\
\hline $\begin{array}{c}\text { Background } \\
\text { concentrations }\end{array}$ & 45 & 83 & 68 & 20 & 95 & 19 & 600 & 47200 \\
\hline
\end{tabular}

Table 3. CF values calculated for each element

\begin{tabular}{ccccccccc}
\hline Metals & $\mathbf{C u}$ & $\mathbf{C r}$ & $\mathbf{N i}$ & $\mathbf{P b}$ & $\mathbf{Z n}$ & $\mathbf{C o}$ & $\mathbf{M n}$ & $\mathbf{F e}$ \\
\hline $\mathbf{C F}_{\text {metal }}-\mathbf{A 2}$ & 0.62 & 1.05 & 4.56 & 1.56 & 0.02 & 1.71 & 2.48 & 0.513 \\
\hline $\mathbf{C F}_{\text {metal }}-\mathbf{A 1 0}$ & 0.8 & 0.86 & 2.99 & 1.06 & 0.46 & 1.43 & 1.95 & 0.409 \\
\hline $\mathbf{C F}_{\text {metal }}-\mathbf{A 1 2}$ & 1.05 & 0.93 & 3.28 & 1.41 & 0.53 & 1.64 & 0.81 & 0.428 \\
\hline $\mathbf{C F}_{\text {metal }}-\mathbf{A 1 4}$ & 0.44 & 0.33 & 1.01 & 1.68 & 0.18 & 1.21 & 1.49 & 0.176 \\
\hline $\mathbf{C F}_{\text {metal }}-\mathbf{L 1}$ & 0.78 & 0.83 & 2.37 & 2.15 & 0.42 & 1.47 & 1.57 & 0.386 \\
\hline $\mathbf{C F}_{\text {metal }}-\mathbf{L 2}$ & 0.77 & 1.3 & 2.26 & 1.99 & 0.43 & 1.52 & 1.6 & 0.449 \\
\hline $\mathbf{C F}_{\text {metal }}-\mathbf{L 3}$ & 0.66 & 0.69 & 2.15 & 1.5 & 0.31 & 1.45 & 1.76 & 0.407 \\
\hline
\end{tabular}




\section{Results and discussion}

The calculation of the PLI, EF and Igeo indices was done according to equations (1) to (6). The concentrations of metals for each sampling area are reported in Table 1. The background concentrations of the respective metals Enrichment Factor are shown in Table 2.

\subsection{Pollution load index, $P L I$}

In Table 3, the CF calculations for each element, at all sampling positions, carried out according to equation (1), are presented. In Table 4, the results of the PLI for each sampling position, according to equation (2), are presented.

Table 4. PLI calculated for all elements in each sampling point

\begin{tabular}{cc}
\hline PLI - A2 & 0.83 \\
\hline PLI - A10 & 1.02 \\
\hline PLI - A12 & 1.04 \\
\hline PLI - A14 & 0.59 \\
\hline PLI - L1 & 1.02 \\
\hline PLI - L2 & 1.1 \\
\hline PLI - L3 & 0.91
\end{tabular}

\subsection{Geoaccummulation index, Igeo}

The total PLI environment according to equation (4) for all the above sampling positions is PLItotal $=0.91$.

Table 5 shows the Igeo calculations for each element at all sampling locations, according to equation (5).

\subsection{Enrichment FACTOR, EF}

In Table 6, EF calculations for each element, at all sampling positions according to equation (6), are presented. Iron was used as the reference metal, the presence of which is natural and the concentration is not due to human influence.

\section{Evaluation of results}

\subsection{Pollution load index}

The Pollution Load Index can show us whether an area or part of an area is contaminated by heavy metals (Harikumar et al., 2009).

- For PLI>1 values, the area is considered contaminated.
- For PLI values $<1$, the area is considered to be unpolluted.

According to the above represented calculations, at 4 sampling points (A10, A12, L1, L2), the PLI was higher than the unit. Thus, the marine zone in Menidi and Paliovarka and the lakes of Rodia and Tsoukalio is considered to be polluted. At the other 3 sampling points (A2, A14, L3), the $\mathrm{PLI}$ was less than one. Thus the marine zone in the Pogonitsa and Vonitsa and Logaros lagoons is considered to be unpolluted. Figure 2 shows the map with the sampling positions and the indication of the pollution that characterizes them.

The total PLI environment for all the above sampling positions is PLItotal $=0.91$. This value, although less than a unit, is very close to it, so the result is not reassuring. We cannot, however, consider it a representative value for the entire Amvrakikos bay because the sampling points used were few in relation to the volume of the bay.

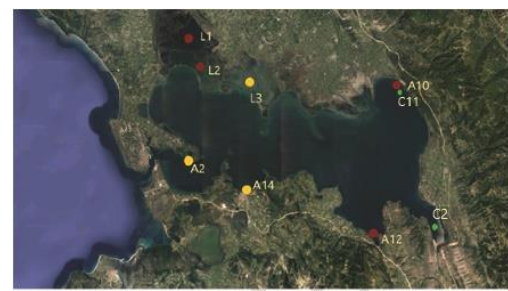

- Area not contaminated by heavy metals.

- Bottom description and TOC

profile.

- Area contaminated by heavy metals.

Figure 2. Area contaminated by heavy metals according to the PLI Index, in Amvrakikos Bay

High PLI values at L1 - Rodia and L2 - Tsoukalio lagoons are determined. Similar studies (Karagiorgos et al., 2006), explain that higher contents of heavy metals in this area due to the fact that the lagoon system is supplied by terrigenous material originating in the Rivers Arachthos and Louros and also directly by the weathering of rock formations. Due to the anticlockwise water circulation prevailing in the Amvrakikos Gulf, particle-rich riverine waters from the Louros River entrain the Tsoukalio and Rodia lagoons. The fact that the positions $\mathrm{A} 10$ and $\mathrm{A} 12$ are close to urban centers is the most likely reason for the high value of PLI index.

Table 5. Igeo calculated by equation (5)

\begin{tabular}{|c|c|c|c|c|c|c|c|c|}
\hline Metals & $\mathrm{Cu}$ & $\mathrm{Cr}$ & $\mathrm{Ni}$ & $\mathrm{Pb}$ & $\mathrm{Zn}$ & Co & $M n$ & $\mathrm{Fe}$ \\
\hline Igeo - A2 & -1.275 & -0.52 & 1.604 & 0.057 & -6.084 & 0.189 & 0.724 & -1.549 \\
\hline Igeo - A10 & -0.903 & -0.804 & 0.993 & -0.51 & -1.712 & -0.07 & 0.381 & -1.875 \\
\hline Igeo - A12 & -0.513 & -0.695 & 1.128 & -0.09 & -1.508 & 0.131 & -0.89 & -1.809 \\
\hline Igeo - A14 & -1.777 & -2.179 & -0.57 & 0.163 & -3.042 & -0.32 & -0.01 & -3.094 \\
\hline Igeo - L1 & -0.952 & -0.862 & 0.658 & 0.519 & -1.847 & -0.03 & 0.064 & -1.96 \\
\hline Igeo - L2 & -0.968 & -0.208 & 0.594 & 0.404 & -1.801 & 0.015 & 0.089 & -1.74 \\
\hline Igeo - L3 & -1.18 & -1.127 & 0.517 & 0 & -2.292 & -0.05 & 0.233 & -1.883 \\
\hline
\end{tabular}

\subsection{Geoaccumulation index}

The Igeo Index is used to assess the degree of metal pollution in terrestrial, aquatic and marine environments. The degree of pollution from metals is distinguished in
6 classes of contamination. Table 7 shows the degree of sediment contamination, according to the Igeo Index.

As can be seen from Table 8 , the Amvrakikos bay is more burdensome $\mathrm{Ni}$ metal, followed by the $\mathrm{Mn}$ and $\mathrm{Pb}$ metals. 
All metals belong to classes 0.1 and 2 . This means that the regions according to the Igeo Index are from unchanged to slightly damage. A possible explanation of these results is the charge by human activities such as industrial waste, urban waste water (lacking sewage treatment facilities) and surface runoff (mainly agriculture and livestock).

Table 6. EF calculated by equation (6)

\begin{tabular}{cccccccc}
\hline Metals & $\mathbf{C u}$ & $\mathbf{C r}$ & $\mathbf{N i}$ & $\mathbf{P b}$ & $\mathbf{Z n}$ & $\mathrm{Co}$ & $\mathbf{M n}$ \\
\hline EF - A2 & 1.21 & 2.04 & 8.89 & 3.04 & 0.04 & 3.34 & 4.83 \\
\hline $\begin{array}{c}\text { EF - } \\
\text { A10 }\end{array}$ & 1.96 & 2.1 & 7.3 & 2.58 & 1.12 & 3.49 & 4.78 \\
\hline $\begin{array}{c}\text { EF - } \\
\text { A12 }\end{array}$ & 2.46 & 2.16 & 7.66 & 3.28 & 1.23 & 3.84 & 1.88 \\
\hline EF - & 2.49 & 1.89 & 5.74 & 9.57 & 1.04 & 6.86 & 8.5 \\
A14 & & & & & & & \\
\hline EF - L1 & 2.01 & 3.95 & 6.14 & 5.58 & 1.08 & 3.82 & 4.07 \\
\hline EF - L2 & 1.71 & 5.33 & 5.04 & 4.42 & 0.96 & 3.37 & 3.55 \\
\hline EF - L3 & 1.63 & 1.69 & 5.28 & 3.69 & 0.75 & 3.56 & 4.33 \\
\hline
\end{tabular}

Table 7. Igeoclassification (Muller, 1969)

\begin{tabular}{ccc}
\hline Igeo & $\begin{array}{c}\text { Igeo }- \\
\text { Class }\end{array}$ & Description of sediment quality \\
\hline$<0$ & 0 & Uncontaminated \\
\hline $0-1$ & 1 & $\begin{array}{c}\text { Uncontaminated to moderately } \\
\text { contaminated }\end{array}$ \\
\hline $1-2$ & 2 & Moderately contaminated \\
\hline $2-3$ & 3 & Moderately to strongly contaminated \\
\hline $3-4$ & 4 & Strongly contaminated \\
\hline $4-5$ & 5 & $\begin{array}{c}\text { Strongly to extremely strongly } \\
\text { contaminated }\end{array}$ \\
\hline 5 & 6 & Extremely contaminated \\
\hline
\end{tabular}

Table 8. Gradient load of Amvrakikos sediments based on the maximum Igeo class for each metal

\begin{tabular}{ccc}
\hline Igeo & Igeo - Class & Metals \\
\hline$<0$ & 0 & $\mathrm{Cu}, \mathrm{Cr}, \mathrm{Zn}, \mathrm{Fe}$ \\
\hline $0-1$ & 1 & $\mathrm{~Pb}, \mathrm{Co}, \mathrm{Mn}$ \\
\hline $1-2$ & 2 & $\mathrm{Ni}$ \\
\hline $2-3$ & 3 & \\
\hline $3-4$ & 4 & \\
\hline $4-5$ & 5 & \\
\hline 5 & 6 & \\
\hline
\end{tabular}

According to Karageorgis et al. (2001), high element (Pb, $\mathrm{Cu}$, and $\mathrm{Zn}$ ) contents and Igeo (geoaccumulation index) values were found for the clay fractions in the northern part of Pagassitikos Gulf. This enrichment is attributed to the discharge of raw domestic and industrial effluents of Volos city and port before the WWTP was installed. The dispersal of pollutants is essentially controlled by diffusion from point sources (city, port and WWTP) and is limited to Volos Bay. Relatively high Mn levels are ascribed to digenetic formation of manganese carbonates (antigenic phase), whereas $\mathrm{Cr}$ and $\mathrm{Ni}$ are elevated due to weathering of ultrabasic formations on land.
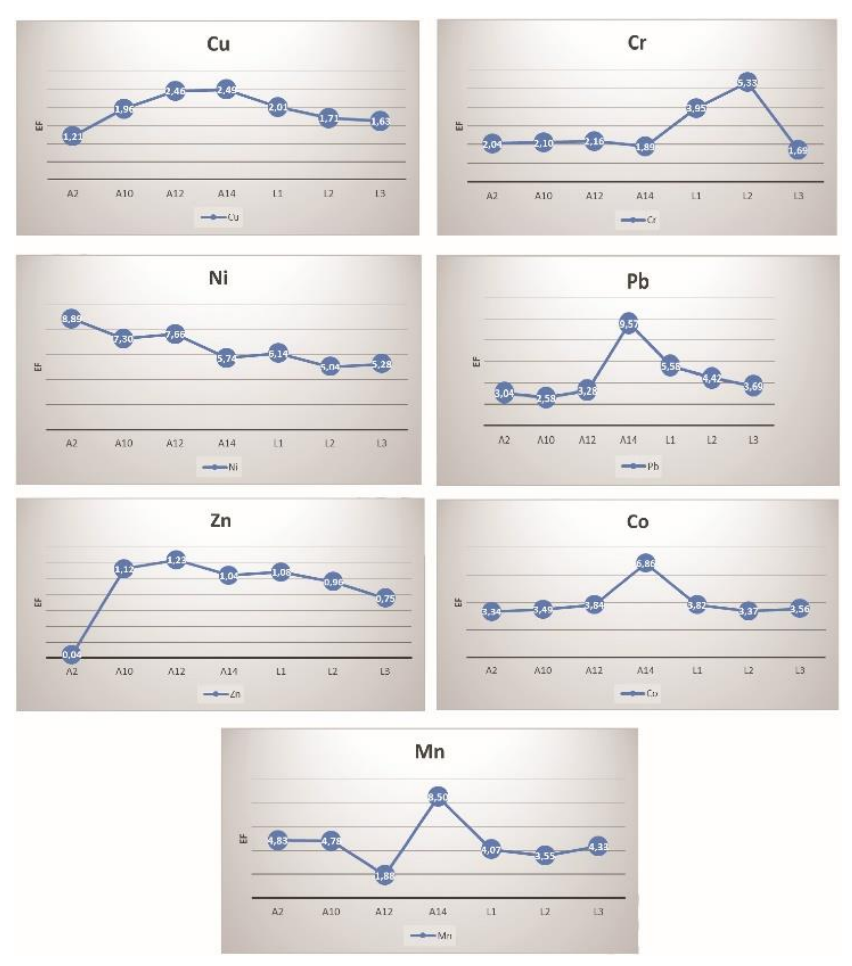

Figure 3. Diagrams Enrichment Factor of $\mathrm{Cu}, \mathrm{Cr}, \mathrm{Ni}, \mathrm{Pb}, \mathrm{Zn}, \mathrm{Co}$, $\mathrm{Mn}$

\subsection{Enrichment factor}

The Enrichment Factor is used to distinguish between metals originating from anthropogenic activities and from natural processes, assessing the degree of anthropogenic effect. In Table 9, the categories of infection according to the Enrichment Factor are presented.

Table 9. Five contaminant categories on the basis of the EF (Sutherland, 2000)

\begin{tabular}{cc}
\hline EF & Contamination Degree \\
\hline$<2$ & Deficiency to minimal enrichment \\
\hline $2-5$ & Moderate enrichment \\
\hline $5-20$ & Significant enrichment \\
\hline $20-40$ & Very high enrichment \\
\hline 40 & Extremely high enrichment \\
\hline
\end{tabular}

Figure 3 shows the graphs of the Metal Enrichment Factor, based on the calculations of Table 9.

$\mathrm{Zn}$ is the metal with the lowest degree of enrichment, with values ranging from 0.04 to 1.23 , while $\mathrm{Cu}$ and has a minimum of enrichment with values from 1.21 to 2.49 . Mn and $\mathrm{Cr}$ belong to the categories of minimum and significant enrichment, with maximum values of 8.5 and 5.33 and minimum values of 1.88 and 1.89 respectively. Co and $\mathrm{Pb}$ show moderate to significant enrichment with minimum values of 3.34 and 2.58 and maximum values of 6.86 and 9.57 respectively. It is worth noting that $\mathrm{Pb}$ showed the maximum enrichment value of all the metals studied. Finally, $\mathrm{Ni}$ belongs to the category of significant enrichment, since all of its values exceed 5 , with a minimum value of 5.04 and a maximum of 8.89 . Based on the above, it is conclude that the concentrations of $\mathrm{Cr}, \mathrm{Mn}$, 
$\mathrm{Co}, \mathrm{Pb}$ and $\mathrm{Ni}$ are significantly affected by various anthropogenic activities.

Similar study from Argostoli Bay (Panagos et al., 1990) of the metals examined $\mathrm{Mo}, \mathrm{Pb}, \mathrm{Cr}, \mathrm{Ni}, \mathrm{Co}$ and $\mathrm{Zn}$ were found to be enriched relative to normal shallow water sediments, their degree of enrichment being in the following order Mo > $\mathrm{Pb}$ > $\mathrm{Cr}$ > $\mathrm{Ni}$ > $\mathrm{Co}$ > $\mathrm{Zn}$. The highest values of $\mathrm{Pb}$ in Argostoli Bay, would suggest that they should be related to the dissemination of oil in sea from the oil tanks occurring at the eastern coast.

Highest values of $\mathrm{EF}$ of $\mathrm{Cu}, \mathrm{Pb}, \mathrm{Co}$ and $\mathrm{Mn}$ in Vonitsa area observed. Due to the fact that this position is very close to the Vonitsa city and there present are significantly influenced by the various anthropogenic activities. Also at Panagos et al. (1990), study highest values of $\mathrm{Cu}$ and $\mathrm{Zn}$ are found at the outfalls of domestic sewage of Argostoli and Lixouri area.

Survey was performed at the beginning of the operation of Athens' sewage primary treatment unit, in the he Saronikos Gulf, indicated a chronic oil-pollution in thesediments. The industrially impacted Elefsis Bay sediments suffered from heavy petroleum pollution, while the sediments near the sewage outfall had a moderate degree of pollution (Sklivagou et al., 2008). The concentration of heavy metals, in Thermaikos Gulf, increased with decreasing mean grain size, suggesting their association with the fine fraction of the sediments, the clays and the organic matter, (Voutsinouu and Varnavas, 1995). In Aetoliko, Greece lagoon, large quantities of pollutants are float on the top of an intermediate cold layers, in the form of particulate matter, (Varnavas, 2005). This studies shows that it is necessary to continuously monitor the natural, chemical and biological characteristics, as well as to take appropriate protective measures immediately in order to preserve the entire ecosystem.

\section{Conclusions}

Climate conditions, area morphology, intense stratification, poor water circulation and renewal, nutrient enrichment, low oxygen concentrations, and high concentrations of metals in sediment are the main causes of degradation of the Amvrakikos ecosystem.

Based on the PLI indicator, for the determination of the metal pollution in the area, the marine zone in Menidi and Paliovarka as well as the Rodia and Tsoukalio lagoons are considered polluted, while the sea zone in the area of Pogonitsa, Vonitsa and the Logaros lagoon are considered unpolluted.

According to the Igeo Index, the sampling areas are unchanged to slightly burden by heavy metals. The largest charge is caused by $\mathrm{Ni}$, followed by $\mathrm{Mn}$ and $\mathrm{Pb}$.

Based on EF, the concentrations of $\mathrm{Cr}, \mathrm{Mn}, \mathrm{Co}, \mathrm{Pb}$ and $\mathrm{Ni}$ are significantly influenced by the various anthropogenic activities.

For the above reasons, it is necessary to continuously monitor the natural, chemical and biological characteristics, as well as to take appropriate protective measures immediately in order to preserve the entire ecosystem. The present approach and their results can be used to monitor the long-term effects in the area.

\section{References}

Achilleopoulos P.P. and Varnavas S.P. (1996), The role of seiches in enrichments of toxic pollatants in Lefkas Channel, Ionian Sea, Greece, Fresenius Environmental Bulletin, 5, 586-591.

Amvrakikos Management Consortium (2009c), Investigation of Abiotic and Biotic Parameters at the Bottom of Amvrakikos Gulf and their Correlation with Fish Production. Hellenic Republic, Prefectural Authority of Arta.

Bearzi G., Agazzi S., Bonizzoni S., Costa M. and Azzellino A. (2008), Dolphins in a bottle: abundance, residency patterns and conservation of bottlenose dolphins Tursiopstruncatus in the semi-closed eutrophic Amvrakikos Gulf, Greece, Aquatic Conservation: Marine and Freshwater Ecosystems, 18, 130146.

Calvert S.E., Pedersen T.F. and Karlin R.E. (2001), Geochemical and isotopic evidence for post-glacial palaeoceanographic changes in Saanich Inlet, British Columbia, Marine Geology, 174, 287-305.

Christia C. and Papastergiadou E. (2006), Ecological study of three lagoons of AmvrakikosRamsar site. Greece, Fresenius Environmental Bulletin, 15(9b), 2006.

Ferentinos G., Papatheodorou G., Geraga M., latrou M., Fakiris E., Christodoulou D., Dimitriou E. and Koutsikopoulos C. (2010), Fjord water circulation patterns and dysoxic/anoxic conditions in a Mediterranean semi-enclosed embayment in the Amvrakikos Gulf, Greece, Estuarine, Coastal and Shelf Science, 88(2010), 473-481.

Harikumar P.S., Nasir U.P. and MujeebuRahma M.P. (2009), Distribution of heavy metals in the core sediments of a tropical wetland system, International Journal.Environmental Science Technology, 6(2), 2009, 225-232.

Huu H.H., Rudy S. and Damme A.V. (2010), Distribution and contamination status of heavy metals in estuarine sediments near Cau Ong harbor, Ha Long Bay, Vietnam. geology Belgica, 13(1-2), 37-47.

Karageorgis A. (2007), Geochemical study of sediments from the Amvrakikos Gulf lagoon complex, Greece, Transitional Waters Bulletin, 1(3): 3-8.

Karageorgis A., Krasakopoulou E., Pappas G., Papageorgiou A. and Taxiarchi M. (2006), Geochemical characteristics of surface sediments from the lagoons of Amvrakikos Gulf, Ionian Sea. 8th Panhellenic Symposium of Oceanography and Fisheries, 2006.

Karageorgis A.P., Sioulas A.I. and Anagnostou C.L. (2001), Use of surface sediments in Pagassitikos Gulf, Greece, to detect anthropogenic influence, Geo-Marine Letters, 21(4), 200-211.

Mediolla L.L., Domingues M.C.D. and Sandoval M.R.G. (2008), Environmental assessment of active tailings pile in the state of Mexico (Central Mexico), Research Journal of Environmental Sciences, 2(3), 197-208.

Muller G. (1969), Index of geoaccumulation in sediments of the Rhine River, Geology Journal, 2, 1969, 109-118.

Panagos A., Alexandropoulos S., Varnavas S. and Agiorgitis G. (1990), Geochemistry of sediments from Argostoli Bay, Cefallonia Island, Greece, Thalassographica, 13(suppl. 2), 2733.

Panagos A., Papadopoulos N., Alexandropoulou S., Synetos S. and Varnavas S. (1989), Geochemical study of sediments from the 
Astakos Bay, Greece, Proceedings of the Conference "Environmental Science and Technology Lesvos, Greece", pp. 231-242.

Sklivagou E., Varnavas S.P., Hatzianestis I. and Kanias G. (2008), Assessment of aliphatic and polycyclic aromatic hydrocarbons and trace elements in coastal sediments of the Saronikos Gulf, Greece (Eastern Mediterranean), Marine Georesources and Geotechnology, 26(4), 372-393.

Sklivagou E., Varnavas S.P. and Hatjianestis J. (2001), Alyphatic and polycyclic aromatic hydrocarbons in surface sediments from Elefsis Bay, Greece (Eastern Mediterranean), Toxicological and Enviromental Chemistry, 79, 195-210.

Sutherland R.A. (2000), Bed sediment-associated trace metals in an urban stream, Oahu, Hawaii, Environmental Geology, 39, 611-37.

Tomlinson D.L., Wilson J.G., Harris C.R. and Jeffney D.W. (1980), Problems in the assessment of heavy metal levels in estuaries and the formation of a pollution index, Helgol Wiss Meeresunters, 33, 566-572.

Turekian K.K. and Wedepohl K.H. (1961), Distribution of the elements in some major units of the earth's crust, Bulletin of the Geological Society of America, 72, 175-192.

Varnavas S.P. (1989). Metal pollution of the Kalloni Bay, Lesvos Greece. Proceedings of the conference "Environmental Science and Technology, Lesvos, Greece", pp. 211-220.

Varnavas S.P. (1991), Behaviour of heavy metals in relation to sedimentation processes in a semienclosedindustrialised embayment Patraikos Bay, Greece. Proceedings of 4th International Conference "Environmental Contamination" Barcelona, Spain, pp. 522-524.

Varnavas S.P. (2005), Environmental conditions in a polluted lagoon. Implications for decontamination planning and management, IASME Transactions, 2(5), 764-768.

Varnavas S.P., Panagos A.G. and Laios G. (1984), Heavy metal distribution in surface sediments from the Kalamata bay, Greece. Proceedings of International Conference of the International Commission for the scientific exploration of the Mediterranean (I.C.S.E.M.) Lucerne, Switzerland, pp 267-274.

Varnavas S.P., Panagos A.G. and Laios G. (1987a), Trace elements in surface sediments of Navarino bay, Greece, Environmental Geology and Water Science, 10(2), 1-10.

Varnavas S.P., Panagos A.G., Laios G. and Alexandropoulou S. (1987b), Heavy metal pollution in the Vathi bay, Ithaki Island, Greece. Proceedings of International Conference «Heavy metals in the Environment» New Orleans, USA, pp. 230-232.

Varnavas S., Kritsotakis K. and Panagos A. (1992), Metal Pollution offshore Hermioni. Greece, related to mining activities. 5th Intern. Conference on "Environmental Contamination", Morges, Switzerland, pp. 78-80.

Varnavas S.P., Kalavrouziotis I.K., Karaberou G., Apostolopoulou K. and Varnavas P.S. (2012), Medical geochemical investigations in taking precautionary measures against diseases.Protection of human health, Global Nest Journal, 14(4), 505-515.

Voutsinou F. and Varnavas S.P. (1985), Distribution of Cr, Zn, Cu, $\mathrm{Pb}$ and organic carbon in surface sediments of Northern Euboicos bay, Greece, Proceedings of International Conference "Heavy Metals in the Environment» held in Athens, C.E.P. Consultants Ltd. Edinburgh, pp 356-358.

Voutsinou -Taliadouri F. and Varnavas S.P. (1992), Geochemical study of sediments from northern Euboekos Bay, Greece with regard to the presence of submarine mineral deposits, Marine Geology, 110, 93-114.

Voutsinou F., Taliadouri and Varnavas S.P. (1995), Geochemical and sedimentological patterns in the Thermaikos Gulf, Northwest Aegean Sea, Formed from a Multisource of Elements, Estuarine, Coastal and Shelf Science, 40, 295-320.

Voutsinou F.-T., Varnavas S.P., Nakopoulou C. and Moriki A. (1997), Dissolved trace elements in south aegean seawater, Marine Pollution Bulletin, 34(10), 840-844. 